\title{
Ірина ПРИЙМАК
}

кандидат економічних наук, доцент, Львівський національний університет імені Івана Франка, Львів, Україна, iryna_pryymak@ukr.net

ORSID ID: 0000-0002-7846-4353

\section{Богдана ВИШИВАНА}

кандидат економічних наук, доцент, Львівський національний університет імені Івана Франка, Львів, Україна, danavyshyvana@ukr.net

ORSID ID: 0000-0002-1206-9975

\section{НЕДЕРЖАВНЕ ПЕНСІЙНЕ ЗАБЕЗПЕЧЕННЯ В СИСТЕМІ СОЦІААЬНОГО ЗАХИСТУ НАСЕАЕННЯ УКРАЇ̈ИИ}

Вступ. Українська система соціального захисту населення, головним джерелом фрінансування якої є бюджетні кошти та кошти державних фрондів соціального страхування, нині не спроможна забезпечити достойного рівня пенсій. Залучення недержавних фрінансових інститутів до вирішення цієї проблеми дає змогу підвищити ефрективність і гнучкість системи соціального захисту населення у старості.

Мета - проаналізувати стан, окреслити проблеми розвитку та розробити практичні рекомендації щодо вдосконалення недержавного пенсійного забезпечення як інструменту соціального захисту осіб пенсійного віку.

Результати. Розкрито сутність і структуру системи соціального захисту населення, яка об'єднує державну та недержавну складові. Проаналізовано динаміку бюджетних видатків на соціальний захист та видатків Пенсійного фронду України. Виявлено зростання дефріциту Пенсійного фронду, що свідчить про глибоку фінансову кризу в пенсійній системі. Оцінено розвиток недержавного пенсійного забезпечення як механізму фрормування додаткових фрінансових ресурсів для виплати пенсій.

Доведено, що недержавні пенсійні фонди (НПФ) є основними фрінансовими інститутами, які забезпечують накопичення пенсійних активів. Аналіз діяльності НПФ в Україні демонструє скорочення їх кількості, перевищення кількості учасників НПФ над кількістю укладених договорів, незначний обсяг внесків від фрізичних осіб, зростання пенсійних виплат, невеликі темпи приросту вартості пенсійних активів, а також диспропорції в обсягах активів за видами НПФ.

Висвітлено роль страхових компаній, які здійснюють страхування життя, в недержавному пенсійному забезпеченні, що полягає в укладенні договорів страхування довічної пенсії з учасниками НПФ, проведенні розрахунку та виплати додаткової пенсії.

Розкрито напрями діяльності банківських установ у системі недержавного пенсійного забезпечення щодо заснування НПФ, виконання ролі банку-зберігача НПФ, обслуго-

() Ірина Ігорівна Приймак, Богдана Михайлівна Вишивана, 2019 
вування діяльності страхових компаній, які займаються пенсійним страхуванням, залучення пенсійних коштів через відкриття пенсійних депозитних рахунків.

Перспективи. Обгрунтовано пропозиції щодо необхідності розроблення виважених раціональних і ефективних управлінських рішень соціально-економічного, нормативноправового, організаційного характеру для підготовки та реалізації ефективної стратегії розвитку недержавного пенсійного забезпечення.

Ключові слова: недержавний пенсійний фонд, страхова компанія, банківська установа, пенсійні внески, пенсійні виплати, пенсійні активи, страхові премії, страхові виплати, пенсійні депозитні рахунки.

Рuс.: 2, табл.: 3, бібл.: 22.

\section{Ирина ПРИЙМАК}

кандидат экономических наук, доцент, Львовский национальный университет имени Ивана Франко, Львов, Украина

\section{Богдана ВЫШЫВАНА}

кандидат экономических наук, доцент, Львовский национальный университет имени Ивана Франко, Львов, Украина

\section{НЕГОСУДАРСТВЕННОЕ ПЕНСИОННОЕ ОБЕСПЕЧЕНИЕ В СНСТЕМЕ СОЦИАЯЬНОЙ ЗАЩИТЫ НАСЕАЕНИЯ УКРАННЫ}

Введение. Украинская система социальной защиты населения, главным источником фринансирования которой являются бюджетные средства и средства государственных фондов социального страхования, в настоящее время не в состоянии обеспечить достойного уровня пенсий. Привлечение негосударственных фринансовых институтов к решению этой проблемы позволяет повысить эффективность и гибкость системы социальной защиты населения в старости.

Цель исследования - проанализировать состояние, обозначить проблемы развития и разработать практические рекомендации по совершенствованию негосударственного пенсионного обеспечения как инструмента социальной защиты лиц пенсионного возраста.

Результаты. Проанализирована структура системы социальной защиты населения, объединяющая государственную и негосударственную составляющие. Проанализирована динамика бюджетных расходов на социальную защиту и расходов Пенсионного фронда Украины. Выявлен рост дефицита Пенсионного фронда, свидетельствующий о глубоком фринансовом кризисе в пенсионной системе. Оценено развитие негосударственного пенсионного обеспечения как механизма фрормирования дополнительных фринансовых ресурсов для выплаты пенсий.

Установлено, что негосударственные пенсионные фоонды (НПФ) являются основными фринансовыми институтами, которые обеспечивают накопление пенсионных активов. Анализ деятельности НПФ в Украине демонстрирует сокращение их количества, превышение количества участников НПФ над количеством заключенных договоров, незначительный объем вкладов от физических лии, рост пенсионных выплат, небольшие темпы прироста стоимости пенсионных активов, а также диспропорции в объемах активов по видам НПФ. 
Освещена роль страховых компаний, осуществляющих страхование жизни, в негосударственном пенсионном обеспечении, состоящая в заключении договоров страхования пожизненной пенсии с участниками НПФ, проведении расчета и выплаты дополнительной пенсии.

Раскрыты направления деятельности банковских учреждений в системе негосударственного пенсионного обеспечения по учреждению НПФ, выполнению роли банка-хранителя НПФ, обслуживанию деятельности страховых компаний, занимающихся пенсионным страхованием, привлечению пенсионных средств через открытие пенсионных депозитных счетов.

Перспективы. Обоснованы предложения о необходимости разработки взвешенных рациональных и эффрективных управленческих решений социально-экономического, нормативно-правового, организационного характера для подготовки и реализации эфрфективной стратегии развития негосударственного пенсионного обеспечения.

Ключевые слова: негосударственный пенсионный фронд, страховая компания, банковское учреждение, пенсионные взносы, пенсионные выплаты, пенсионные активы, страховые премии, страховые выплаты, пенсионные депозитные счета

\section{Iryna PRYIMAK,}

Ph. D. (Economics), Assoc. Prof., Ivan Franko National University, Lviv, Ukraine, iryna_pryymak@ukr.net

ORSID ID: 0000-0002-7846-4353

\section{Bohdana VYSHYVANA}

Ph. D. (Economics), Assoc. Prof., Ivan Franko National University, Lviv, Ukraine, danavyshyvana@ukr.net ORSID ID: 0000-0002-1206-9975

\section{NON-STATE PENSION PROVISION IN THE SYSTEM OF SOCIAL PROTEC- TION OF THE UKRAINIAN POPULATION}

Introduction. The Ukrainian system of social protection, which is mainly financed by the budget funds and funds of state social insurance funds, is currently unable to provide a decent level of pensions. Involving non-state financial institutions in solving this problem allows to increase the efficiency and flexibility of the system of social protection of the population in old age.

Purpose. The purpose of the article is to analyze the situation, outline the problems of development and develop practical recommendations for improving the non-state pension provision as an instrument of social protection for people of retirement age.

Results. The essence and structure of the system of the population social protection is uncovered, which unites state and non-state constituents. The dynamics of budget expenditures on social protection and expenditures of the Pension Fund of Ukraine are analyzed. The increasing deficit of the Pension Fund has been revealed, which indicates a profound financial crisis in the pension system. There has been made an evaluation of the development of nonstate pension provision as a mechanism for the formation of additional financial resources for the payment of pensions. 
It has been established that non-state pension funds (NPFs) are the main financial institutions that provide accumulation of pension assets. The analysis of NPF activity in Ukraine shows a reduction in their number, exceeding the number of NPF participants over the number of contracts concluded, a small amount of contributions from individuals, an increase in retirement benefits, a slight increase in the value of retirement assets, as well as imbalances in the volume of assets by types of NPFs.

There has been highlighted the role of life insurance companies in non-state pension provision, which consists in entering into life insurance pension insurance contracts with an NPF participant, calculation and payment of an additional pension.

The directions of activity of banking institutions in the system of non-state pension provision regarding the establishment of an NPF, the role of the custodian bank of NPF, maintenance of insurance companies engaged in pension insurance, and the attraction of pension funds through the opening of pension deposit accounts are disclosed.

Conclusions. The proposals on the necessity of developing well-balanced rational and effective of socio-economic, normative-legal, organizational management decisions for the preparation and implementation of an effective strategy for the development of non-state pension provision, are substantiated.

Keywords: non-state pension fund, insurance company, banking institution, pension contributions, pension payments, pension assets, insurance bonuses, insurance payments, pension deposit accounts.

JEL Classification: G20, G21, G22, G23, H55.

Постановка проблеми. Ефективна система соціального захисту населення головна ознака сучасної економічно розвинутої держави, важливою функцією якої $€$ підвищення добробуту та життєвого рівня громадян. Розвиток і реформування української економіки, сучасні політичні та воєнні виклики, зміна демографічної ситуації, посилення трудової міграції населення обумовлюють потребу в запровадженні сучасних інструментів і механізмів нейтралізації соціальних ризиків.

Традиційно головним джерелом фінансування системи соціального захисту населення України $€$ кошти державного та місцевих бюджетів, а також фондів загальнообов'язкового державного соціального страхування. Однак вагому роль у подоланні низки соціальних ризиків, серед яких - досягнення пенсійного віку, покриття витрат на лікування, втрата працездатності, відіграють недержавні фінансові інститути (недержавні пенсійні фонди, страхові компанії, банки) та благодійні організації. Треба зазначити, що в українських реаліях, на відміну від економічно розвинутих країн, роль недержавних фрінансових інститутів у формуванні фрінансових ресурсів соціального захисту залишається недостатньою, а їх потенціал у підвищенні добробуту українців недооцінений.

Аналіз останніх досліджень і публікацій. Вагомий внесок у дослідження фінансово-економічних аспектів розвитку системи соціального захисту населення як ефективного механізму нейтралізації соціальних ризиків зробили такі українські та зарубіжні вчені: Л. Баранник, В. Дем'янишин, Л. Ерхард [L. Erhard], Л. Лисяк, Е. Лібанова, А. Мерзляк, Д. Міщенко, 
Е. Нікбахт [E. Nikbaht], К. Павлюк, М. Ріппа, O. Степанова, С. Фішер [S. Fisher]. Проблемам функціонування пенсійної системи та недержавного пенсійного забезпечення в Україні присвячені праці М. Демченко, А. Іващенко, В. Корнєєва, Д. Третяк, М. Шульги та інших.

Попри вагомий доробок учених у цій сорері, треба зазначити, що питання фрінансового забезпечення соціального захисту осіб пенсійного віку та пошук ефективних інструментів його удосконалення в Україні потребують ґрунтовних подальших досліджень. Особливу увагу доцільно зосередити на пошуку напрямів активізації розвитку недержавного пенсійного забезпечення як джерела додаткових доходів при виході на пенсію.

Метою дослідження $€$ проведення аналізу системи недержавного пенсійного забезпечення в Україні як складової соціального захисту населення, визначення основних проблем і розроблення рекомендацій щодо розвитку та популяризації недержавних пенсійних програм.

Виклад основного матеріалу дослідження. Система соціального захисту населення, яка, з одного боку, дає можливість надавати матеріальну підтримку громадянам у складних життєвих ситуаціях, а з іншого встановлює головні економічні, соціальні, політичні та правові умови для забезпечення їх достойного життя, є важливим надбанням сучасного суспільства. Ефективна робота такої системи дає можливість оптимально перерозподілити обмежені фрінансові ресурси та максимально нейтралізувати дію основних соціальних ризиків, забезпечивши кожному члену суспільства можливість реалізувати своє право на гідне життя.

Конституція (ст. 46) гарантує громадянам України “право на соціальний захист, що включає право на забезпечення їх у разі повної, часткової або тимчасової втрати працездатності, втрати годуваль- ника, безробіття з незалежних від них обставин, а також у старості та в інших випадках" [1], водночас визначаючи завдання соціального захисту - забезпечити рівень життя не нижче прожиткового мінімуму, встановленого законодавством. Фінансовою основою для реалізації цього права $є$ кошти загальнообов'язкового державного соціального страхування, які формуються з внесків громадян і роботодавців, а також бюджетні кошти та інші джерела соціального забезпечення [1].

Соціальний захист як сукупність фрінансових, соціально-економічних, організаційних і правових інструментів забезпечення гідного життя та добробуту кожного громадянина має виконувати дві головні функції: боротьба з бідністю (лікувальна функція) та попередження бідності (профілактична). Друга функція означає, що кожен працівник упродовж своєї трудової діяльності повинен мати можливість заощадити достатньо фінансових ресурсів, щоб забезпечити собі достойний рівень життя в періоди тимчасової непрацездатності та після досягнення пенсійного віку [2, 31].

Українська система соціального захисту населення об'єднує три головні складові: - соціальне страхування (пенсійне, від нещасних випадків на виробництві, медичне, на випадок тимчасової втрати працездатності);

- соціальна допомога (допомога непрацездатним і малозабезпеченим громадянам, житлові виплати);

- соціальні гарантії (прожитковий мінімум, мінімальний розмір заробітної плати, мінімальний розмір пенсії, індексація грошових доходів тощо).

У нашому суспільстві склалося стійке переконання, що вирішення соціальних проблем, виплата та постійне підвищення пенсій, оплата медичних послуг, гарантія безпеки на робочому місці тощо має повністю 
забезпечувати держава. Однак система соціального страхування, на нашу думку, буде більш ефективною й еластичною, якщо до нейтралізації соціальних ризиків будуть залучені недержавні фрінансові інститути, підприємства та громадяни (рис. 1).

Щороку понад 25\% видатків зведеного бюджету спрямовується на фінансування програм соціального захисту (рис. 2). Бюджетні видатки за цією статтею зросли у 6 разів - з 48,3 млрд грн у 2007 р. до 309,4 млрд грн у 2018 р. Частка соціальних видатків у структурі видатків зведеного бюджету України коливалася від 21\% у 2007 р. до майже 31\% у 2016 р. Упродовж 2017-2018 рр., попри зростання номінального обсягу соціальних видатків, їх частка скоротилася до майже 25\%. Така ситуація значною мірою обумовлена скороченням видатків на виплату житлових субсидій.
Найбільшу частину соціальних видатків спрямовують на виплату пенсій, обсяг яких постійно зростає та у 2018 р. становив 99,4 млрд грн. Високими є й темпи зростання видатків Пенсійного фонду України, які тільки у 2018 р. збільшилися на 67,1 млрд грн. Така ситуація насторожує, адже відбувається зростання дефіциту Пенсійного фонду України, який у 2018 р. сягнув свого максимуму за останніх 12 років (28\%). Очевидно, що українська пенсійна система перебуває в гострій фрінансовій кризі та потребує негайних кардинальних реформ, а не "косметичних заходів", таких як спрямування коштів від розмитнення автомобілів на "єврономерах" до Пенсійного фонду.

Попри зростання державних видатків на пенсійне забезпечення розмір середньої місячної пенсійної виплати у 2018 р. сягнув близько 100 дол. США. Водночас у сусідній

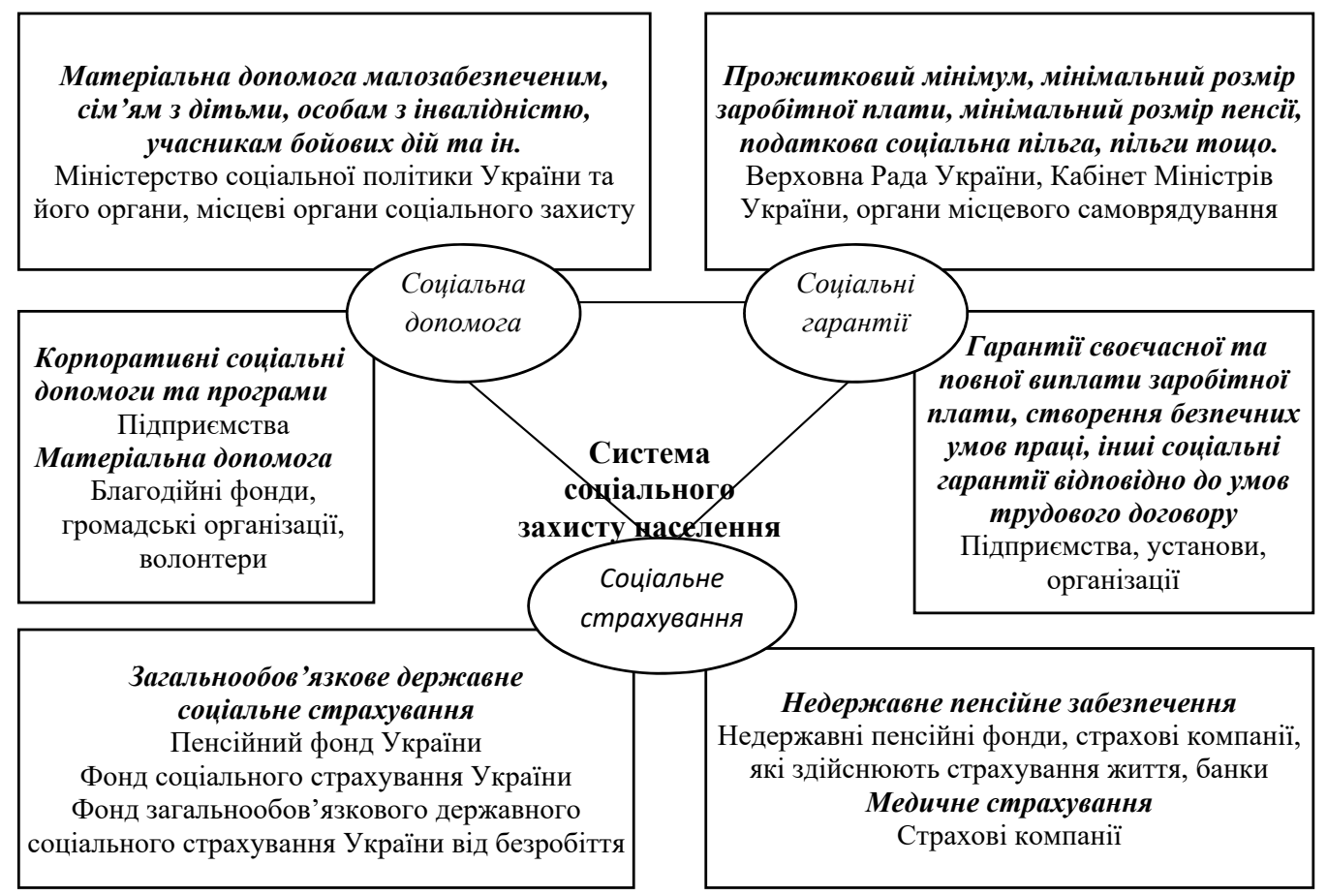

Рис. 1. Структура системи соціального захисту населення України* *Побудовано авторами. 


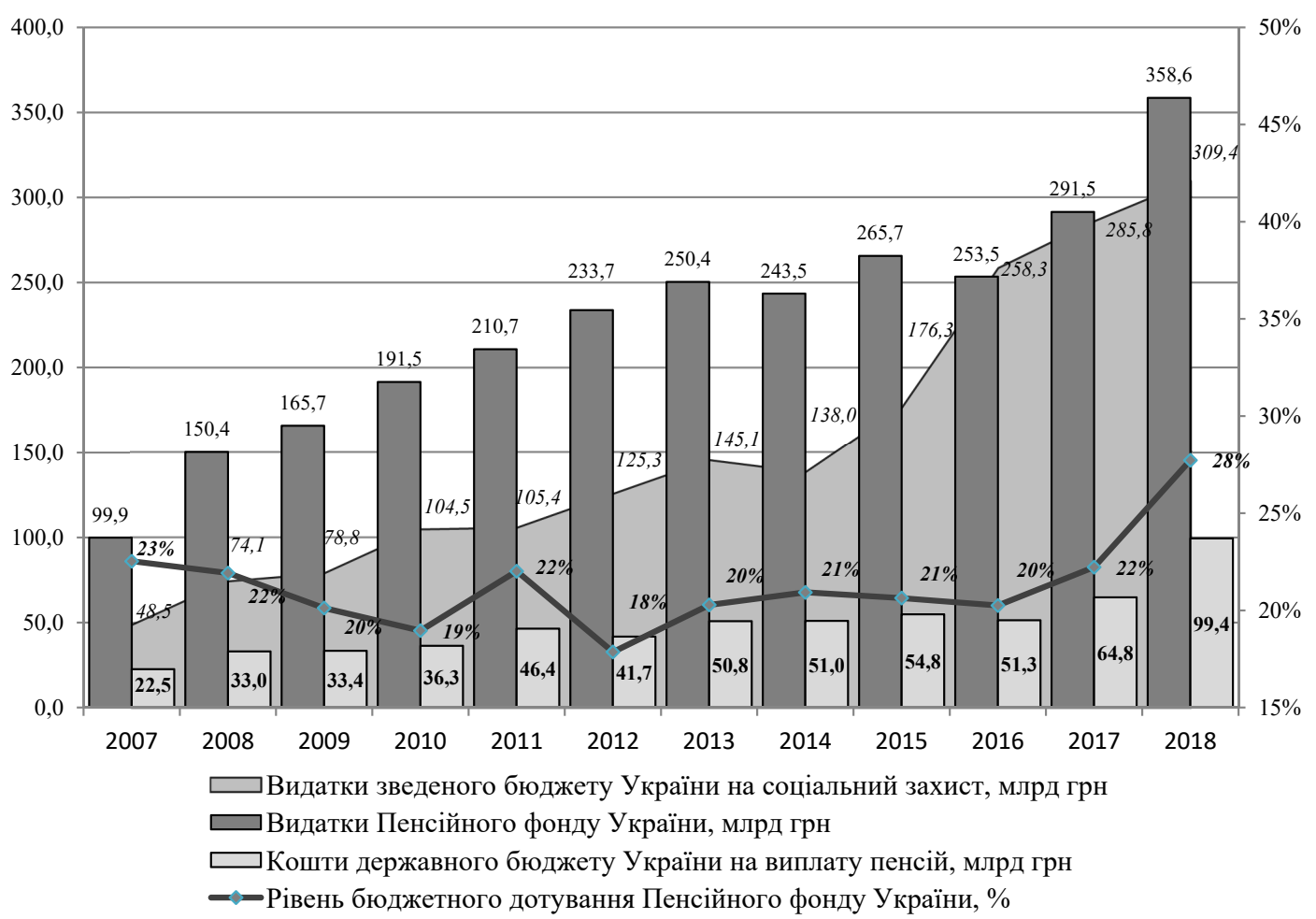

Рис. 2. Динаміка видатків зведеного бюджету України на соціальний захист та видатків Пенсійного фонду України*

* Побудовано на основі [3; 4].

Польщі, де працює трирівнева пенсійна система, пенсіонер у середньому отримує 460 дол. США [5]. Польські пенсіонери можуть отримувати не лише базову солідарну пенсію, а й накопичити кошти на додаткову пенсію. В Україні вже понад десять років відкладають запровадження другого обов'язкового накопичувального рівня пенсійної системи, а недержавне пенсійне забезпечення ще не стало загальноприйнятим і поширеним механізмом формування пенсійних заощаджень.

Однією із найважливіших складових соціального захисту громадян $€$ пенсійна система, яка, згідно з українським законодавством, має трирівневу структуру: загальнообов'язкове державне пенсійне страхування (1 рівень), накопичувальний пенсійний фронд (2 рівень) та недержавне пенсійне забезпечення (3 рівень) [6]. Нині в Україні працюють тільки перший і третій рівні, запровадження ж другого рівня пенсійної системи знову відтерміновують. За рахунок загальнообов'язкового державного пенсійного страхування пенсії отримують майже всі громадяни, які досягли пенсійного віку, за наявності необхідного страхового стажу. Однак Пенсійний фонд України, який має постійний десіцит коштів і на третину дотується з державного бюджету, не спроможний забезпечити достойного рівня пенсійних виплат. За відсутності обов'язкового накопичувального пенсійного страхування тільки недержавне пенсійне забезпечення дає змогу кожному громадянину заощадити кошти на безбідну старість. Водночас через 
складну економічну ситуацію в країні, низький рівень доходів працюючого населення, недовіру до недержавних фрінансових установ приватні пенсійні програми не набули достатньої популярності серед українців.

На рівень розвитку недержавного пенсійного забезпечення в країні вказує обсяг сформованих пенсійних активів. На кінець 2017 р. недержавні пенсійні фонди України акумулювали близько 87 млн дол. США [7], тоді як обсяг приватних пенсійних активів у США становив 28169,0 млрд дол. США, у Великій Британії - 2903,3 млрд дол. США, в Нідерландах - 1627,8 млрд дол. США, в Німеччині - 270,7 млрд дол. США, в Італії - 200,9 млрд дол. США, в Польщі 57,6 млрд дол. США [8]. Як бачимо, через низку економічних, політичних і демографічних чинників обсяг ринку недержавного пенсійного забезпечення залишається мізерним.

Проаналізуємо стан та проблеми розвитку недержавного пенсійного забезпечення як одного 3 головних напрямів удосконалення соціального захисту осіб пенсійного віку. Законом України "Про недержавне пенсійне забезпечення” визначено три способи його проведення [9]:

- пенсійними фондами шляхом укладення пенсійних контрактів між адміністраторами пенсійних фондів і вкладниками таких фрондів;

- страховими організаціями шляхом укладення договорів страхування довічної пенсії з учасниками фонду, страхування ризику настання інвалідності або смерті учасника фронду;

- банківськими установами шляхом укладення договорів про відкриття пенсійних депозитних рахунків для накопичення пенсійних заощаджень у межах суми, визначеної для відшкодування вкладів Фондом гарантування вкладів фрізичних осіб.

Недосконалість і неефективність сучасної системи загальнообов'язкового державного пенсійного страхування зумовлюють необхідність активізації розвитку недержавних пенсійних фондів (НПФ). Важливість таких фондів характеризує їх спроможність стати вагомим джерелом підтримки високих соціальних стандартів і водночас чинником зростання внутрішніх інвестиційних ресурсів для прискореного розвитку національної економіки.

Відповідно до Закону України “Про недержавне пенсійне забезпечення" [9] НПФ має статус неприбуткової організації, фрункціонує та провадить діяльність виключно з метою накопичення пенсійних внесків на користь учасників із подальшим управлінням пенсійними активами, а також здійснює пенсійні виплати учасникам у визначеному законодавством порядку. Важливо зазначити, що, на відміну від інших інститутів, які надають послуги в системі недержавного пенсійного забезпечення, зокрема страхових компаній та банківських установ, саме для НПФ основним видом діяльності $\epsilon$ пенсійне забезпечення громадян. Закон передбачає участь у діяльності НПФ адміністратора фонду, компанії з управління активами та банку-зберігача.

Проаналізуємо сучасний стан і динаміку показників, які характеризують діяльність НПФ в Україні. Згідно з даними Національної комісії, що здійснює державне регулювання у сфері ринків фрінансових послуг (Нацкомфінпослуг), станом на 31.12.2018 р. в Україні працювало 62 НПФ, зареєстровані у 8 регіонах України. Спостерігаємо тенденцію до зменшення чисельності НПФ упродовж 2014-2018 рр. на 18,4\% з 76 (станом на 31.12.2014р.) до 62 (станом на 31.12.2018 р.) і, відповідно, зміну їх територіального розподілу за рахунок надання АР Крим статусу тимчасово окупованої території та зменшення кількості НПФ, зареєстрованих в м. Києві. Зважаючи на те, що понад 70\% всіх зареєстрованих на території Укра- 
їни НПФ розташовані в м. Києві (44 станом на 31.12.2018 р.) [10], можемо помітити нерівномірність їх регіонального розподілу.

Головні показники діяльності НПФ упродовж 2014-2018 рр. наведені в табл. 1. Адміністраторами НПФ укладено 68,8 тис. пенсійних контрактів, що на 24,9\% більше, порівняно з аналогічним періодом 2014 р. Найбільше контрактів укладено з вкладниками фрізичними особами (61,9 тис. або 90,0\%). Переважну більшість учасників НПФ становили особи віком від 25 до 50 років $(60,1 \%)$ та особи вікової групи від 50 до 60 років $(26,9 \%)$ [10]. Як показують дані табл. 1 загальна кількість учасників НПФ значно перевищує кількість укладених пенсійних контрактів. Така ситуація може свідчити про лише номінальну кількість учасників у реєстрах НПФ, які не уклали пенсійних контрактів і не сплачують пенсійних внесків.

Одним із важливих якісних показників, що характеризують вітчизняну систему недержавного пенсійного забезпечення, $€$ сплачені пенсійні внески, сума яких на звітну дату становила 2000,5 млн грн, що на 192,3 млн грн, або 10,6\% більше відповідного показника аналогічного періоду 2014 р. Зауважимо, що впродовж досліджуваного періоду в загальній сумі пенсійних внесків понад 90,0\% становлять внески від юридичних осіб. Пенсійні внески від фізичних осіб $є$ порівняно незначними, однак їх суми станом на 31.12.2018 р. зросли на 141,0\% (100,7 млн грн) проти відповідного показника 2014 р., що свідчить про поступове зростання довіри населення до НПФ.

Пенсійні виплати (одноразові та на визначений строк) станом на 31.12.2018 р. збільшилися, порівняно 3 аналогічним періодом 2014 р., на 92,2\% і становили 809,9 млн грн. Доцільно зауважити, що протягом досліджуваного періоду більшу частину пенсійних виплат становлять однора- зові (від 91,3\% станом на 31.12.2014 р. до $67,4 \%$ станом на 31.12.2018 р.), темп приросту яких в 2018 р. проти 2014 р. становив $41,8 \%$. Водночас пенсійні виплати на визначений строк, незважаючи на невелику частку в структурі пенсійних виплат, в динаміці збільшилися на 618,5\% або 227,6 млн грн.

Ще одним важливим показником ефективності діяльності НПФ в Україні є вартість їх активів. Загальна вартість активів, сформованих НПФ, станом на 31.12.2018 р. становила 2745,2 млн грн, що на 11,2\% або 276 млн грн більше, порівняно з аналогічним періодом 2014 р. (див. табл. 1) [7; 10; 11]. Зауважимо, що впродовж досліджуваного періоду темпи приросту цього показника коливалися, зокрема в 2015 р. загальна вартість активів НПФ зменшилася на 19,8\% проти 2014 р., у 2016 р. зросла на 8,0\% щодо показника 2015 р., у 2017 р. зросла на 15,3\%, порівняно з аналогічним періодом 2016 р., а в 2018 р. - на 11,3\%, проти показника 2017 р. [7; 10; 11].

Варто наголосити, що, за даними Української асоціації інвестиційного бізнесу, станом на 31.12.2018 р. з 62 зареєстрованих в Україні НПФ 58 перебувають в управлінні КУА, з них 45 НПФ відкритого типу, 7 корпоративних і 6 - професійних [12]. Крім того, кількість НПФ, які подали звітність щодо складу та дохідності активів, менша, ніж кількість фондів, активи яких перебувають в управлінні КУА $[13,11]$.

Аналіз вартості активів НПФ в управлінні КУА за видами фондів (без урахування КНПФ НБУ) показує, що найбільшими за обсягом активами володіють відкриті НПФ, а найменшими - професійні [12; 14]. Проте в 2018 р. приріст пенсійних активів у відкритих і професійних НПФ був однаковим (14,8\%). Майже половиною $(50,3 \%)$ сукупної вартості активів усіх НПФ станом на 31.12.2018 р. володів корпоративний НПФ НБУ, який є лідером серед НПФ України [12]. 
Динаміка показників діяльності НПФ в Україні*

\begin{tabular}{|c|c|c|c|c|c|c|}
\hline \multirow[b]{2}{*}{ Показники } & \multicolumn{5}{|c|}{ Станом на } & \multirow{2}{*}{\begin{tabular}{|c|} 
Темп \\
приросту, \% \\
$31.12 .2018 /$ \\
31.12 .2014 \\
\end{tabular}} \\
\hline & $\begin{array}{c}31.12 . \\
2014\end{array}$ & $\begin{array}{c}31.12 . \\
2015\end{array}$ & $\begin{array}{c}31.12 . \\
2016\end{array}$ & $\begin{array}{c}31.12 . \\
2017\end{array}$ & $\begin{array}{c}31.12 . \\
2018\end{array}$ & \\
\hline Загальна кількість учасників НПФ, тис. осіб & 833,7 & 836,7 & 834,0 & 840,8 & 855,3 & 2,6 \\
\hline Кількість укладених пенсійних контрактів, тис. & 55,1 & 59,7 & 62,6 & 58,7 & 68,8 & 24,9 \\
\hline Пенсійні внески, всього, млн грн, у т. ч.: & 1808,2 & 1886,8 & 1895,2 & 1897,3 & 2000,5 & 10,6 \\
\hline від фрізичних осіб & 71,4 & 80,3 & 92,2 & 124,3 & 172,1 & 141,0 \\
\hline від фрізичних осіб-підприємців & 0,2 & 0,2 & 0,2 & 0,2 & 0,2 & 0,0 \\
\hline від юридичних осіб & 1736,1 & 1806,3 & 1802,1 & 1772,3 & 1827,7 & 5,3 \\
\hline Пенсійні виплати, млн грн, у т.ч.: & 421,4 & 557,1 & 629,9 & 696,3 & 809,9 & 92,2 \\
\hline одноразові пенсійні виплати & 384,6 & 475,7 & 499,4 & 505,9 & 545,5 & 41,8 \\
\hline пенсійні виплати на визначений строк & 36,8 & 81,4 & 130,5 & 190,4 & 264,4 & 618,5 \\
\hline Загальна вартість активів НПФ, млн грн & 2469,2 & 1980,0 & 2138,7 & 2465,6 & 2745,2 & 11,2 \\
\hline
\end{tabular}

* Побудовано на основі [7; 10; 11].

Зазначимо, що діяльність НПФ ґрунтується на інвестиційному використанні залучених ресурсів і, зважаючи на соціальну місію системи недержавного пенсійного забезпечення, та водночас ії̈ залежність від рівня розвитку вітчизняного фрінансового ринку і його інструментів, важливе значення мають напрями інвестування пенсійних активів, а також ефективне управління ризиками, які при цьому виникають. Для НПФ надзвичайно важливо сформувати портфель активів, який охоплюватиме об'єкти інвестування з мінімальним ступенем ризику. Тому особливе значення має вибір інвестиційних інструментів, використовуючи які НПФ зможе забезпечити захист коштів вкладників від інфляції і водночас отримувати визначений приріст капіталу.

Зважаючи на консервативнішу, ніж у інших фрінансових установ, інвестиційну стратегію, головними напрямами інвестування пенсійних активів НПФ станом на 31.12.2018 р. були державні цінні папери (46,0\%), банківські депозити $(35,9 \%)$ та облігації вітчизняних підприємств $(10,9 \%)$ [10]. Зокрема в 2018 р. спостерігаємо при- ріст вкладень у державні цінні папери (на $25,7 \%$ ) та облігації українських емітентів (на 47,5\%), водночас на 24,4\% зменшився обсяг активів, вкладених в об'єкти нерухомості. Крім того, на відміну від 2017 р., у 2018 р. значно збільшилося інвестування пенсійних активів в акції українських емітентів (на 287,6\% або 32,5 млн грн). Попри мізерну частку в загальній вартості пенсійних активів акцій іноземних емітентів, варто відзначити поступове зростання інвестицій в ці фрінансові інструменти, зважаючи на їх високу надійність. Загальний дохід, отриманий від інвестування пенсійних активів, з 2016 р. демонструє тенденцію до зростання, незважаючи на те, що його приріст у 2018 р. був меншим, ніж у 2017 р. [7; 10; 11].

Незважаючи на позитивні тенденції функціонування НПФ, приріст доходу та збільшення обсягів акумульованих пенсійних активів, частка останніх залишається мізерною. Порівняно з бюджетом Пенсійного фонду України обсяг активів усіх НПФ не досягає 1\%. 3 огляду на це, особливої актуальності набуває популяризація не- 
державного пенсійного страхування та необхідність зростання доходів населення.

Стосовно ролі страхових компаній у недержавному пенсійному забезпеченні завжди відбувалися дискусії. 3 одного боку, законодавство обмежує можливість страховиків збирати пенсійні внески та зводить їхню роль до виплати накопичених пенсій, але з іншого - страховики можуть запропонувати ширший перелік продуктів та поєднати накопичення коштів зі страховим захистом клієнтів від нещасних випадків і медичним страхуванням.

Страхування додаткової пенсії або страхування ануїтетів у світовій практиці є одним із найефективніших інструментів соціального захисту при виході на пенсію. У більшості економічно розвинутих країн рівень довіри до страхового ринку в цілому та до страхових компаній, які здійснюють страхування життя зокрема, доволі високий. Наприклад, в Польщі 66\% індивідуальних пенсійних рахунків та 70\% індивідуальних рахунків підвищеної безпеки з пенсійного забезпечення розміщені в страхових компаніях, які $€$ фрактично лідерами польського ринку недер- жавного пенсійного забезпечення [15, 16]. В Україні ж спостерігаємо протилежну ситуацію, адже через законодавчі обмеження, низький рівень доходів населення, складну економічну ситуацію та недовіру до страхових компаній, ринок страхування життя розвинутий недостатньо (табл. 2).

Впродовж шести років кількість страхових компаній, які здійснюють страхування життя, зменшилася вдвічі, а тих, які укладають договори пенсійного страхування, залишилося тільки чотири (ПАТ "Страхова компанія “ТАС”, ПАТ “Страхова компанія ПЗУ Україна страхування життя”, ПАТ "Українська Акціонерна Страхова Компанія АСКА-ЖИТТЯ" ПАТ “Акціонерна страхова компанія “ІНГО Україна Життя").

Така ситуація обумовлена законодавчими обмеженнями щодо ролі страхових компаній в недержавному пенсійному забезпеченні. Починаючи з 2012 р., фрункція “лайфрових" страхових копаній зводиться до розрахунку і проведення виплати довічної (ануїтетної) пенсії учаснику НПФ. Страховики позбавлені можливості самостійно акумулювати пенсійні активи. Проте,

Таблиця 2

Основні показники ринку страхування життя та недержавного пенсійного страхування*

\begin{tabular}{|c|c|c|c|c|c|c|}
\hline \multirow[b]{2}{*}{ Показники } & \multicolumn{6}{|c|}{ Станом на } \\
\hline & $\begin{array}{c}31.12 . \\
2013\end{array}$ & $\begin{array}{c}31.12 . \\
2014\end{array}$ & $\begin{array}{c}31.12 . \\
2015\end{array}$ & $\begin{array}{l}31.12 . \\
2016\end{array}$ & $\begin{array}{l}31.12 . \\
2017\end{array}$ & $\begin{array}{c}31.12 . \\
2018\end{array}$ \\
\hline Кількість СК life & 62 & 57 & 49 & 39 & 33 & 30 \\
\hline $\begin{array}{l}\text { Кількість CK life, які укладали договори } \\
\text { пенсійного страхування }\end{array}$ & 13 & 10 & 8 & 5 & 4 & 4 \\
\hline Валові страхові премії, млн грн & 2476,7 & 2159,8 & 2186,6 & 2756,1 & 2913,7 & 3906,1 \\
\hline $\begin{array}{l}\text { в т. ч. за договорами пенсійного } \\
\text { страхування млн грн }\end{array}$ & 46,8 & 24,0 & 19,6 & 10,2 & 29,9 & 44,5 \\
\hline Валові страхові виплати, млн грн & 149,2 & 239,2 & 419,6 & 418,3 & 556,3 & 704,9 \\
\hline Рівень страхових виплат, \% & 6,0 & 11,1 & 22,5 & 15,2 & 19,1 & 18,0 \\
\hline $\begin{array}{l}\text { Кількість договорів страхування життя, } \\
\text { укладених за рік, млн. шт. }\end{array}$ & 3,48 & 0,97 & 1,95 & 0,65 & 1,28 & 2,65 \\
\hline
\end{tabular}

*Побудовано на основі [16] 
відповідно до законодавства, вони можуть здійснювати накопичувальне страхування життя громадян впродовж певного терміну, до досягнення пенсійного віку або іншого, визначеного договором, віку [17, 80].

Водночас можемо спостерігати деяке пожвавлення на ринку страхування життя в цілому та пенсійного страхування зокрема після кризи 2014-2016 рр. Про це свідчить зростання валових страхових премій і динаміка кількості укладених договорів зі страхування життя. Попри скорочення кількості страхових компаній на ринку страхування життя простежується тенденція до зростання обсягу та рівня страхових виплат. Така тенденція пов'язана із закінченням дії договорів, які укладали 10 років тому. Вважаємо, що стабільне, своєчасне та повне проведення таких виплат сприятиме зростанню популярності страхування життя як інструменту соціального захисту.

Банківська складова у системі недержавного пенсійного забезпечення $€$ найменш розвиненою. Серед можливих напрямів діяльності банківських установ у системі недержавного пенсійного забезпечення можна назвати такі:

1. Реалізація права бути засновником недержавного пенсійного фонду. У разі створення власного корпоративного пенсійного фонду банк має право управляти активами та забезпечувати адміністрування фонду за умови отримання відповідних ліцензій. Право самостійно здійснювати адміністрування, зберігання й управління активами створеного ним корпоративного пенсійного фонду на підставі відповідних ліцензій має Національний банк України [9].

2. Виконання функцій банку-зберігача недержавного пенсійного фонду за умови наявності ліцензії Національної комісії 3 цінних паперів і фондового ринку на провадження діяльності зі зберігання активів пенсійних фондів. Банк-зберігач відкриває та веде рахунки НПФ; забезпечує приймання, передачу (переведення), облік і зберігання цінних паперів, а також документів, які підтверджують право власності на пенсійні активи в інших формах, документів, пов'язаних із формуванням та використанням пенсійних активів; перевіряє підрахунок чистої вартості активів пенсійного фонду і чистої вартості одиниці пенсійних внесків, проведений адміністратором та особою (особами), що провадить (провадять) діяльність з управління активами пенсійного фонду; виконує розпорядження адміністратора щодо перерахування пенсійних коштів; подає звітність і виконує інші функції, передбачені законодавством [9].

3. Обслуговування діяльності страхових компаній, які займаються пенсійним страхуванням, зокрема надання консультаційних, агентських, брокерських послуг, розрахунково-касове обслуговування [18, с. 91].

4. Безпосереднє залучення пенсійних коштів через відкриття пенсійних депозитних рахунків, які банки відкривають для клієнтів на договірній основі для накопичення заощаджень на виплату пенсії. Відповідно до Закону України “Про недержавне пенсійне забезпечення" [9], сума коштів на таких рахунках не повинна перевищувати визначену для відшкодування Фондом гарантування вкладів фрізичних осіб (ФГВФО). Розмір гарантованої суми для відшкодування Фондом нині становить 200000 грн [19].

Пенсійні депозитні рахунки належать до вкладних (депозитних) рахунків, які банки відкривають клієнтам на договірній основі для зберігання грошей, переданих в управління на встановлений строк або без зазначення такого строку під визначений процент (дохід), що підлягають поверненню клієнту відповідно до законодавства та умов договору [20].

Станом на початок 2019 р. банками-лідерами щодо залучення коштів фрізичних 
осіб на вкладні рахунки були АТ КБ “ПРИВАТБАНК”, частка якого на депозитному ринку України становить 34,9\%, АТ "Ощадбанк” (18,9\%), АТ “АЛЬФА-БАНК” (6,29\%), АТ "Укрексімбанк" (5,2\%) та АТ "Райфрфайзен Банк Аваль” (4,7\%) [21]. Проте спеціальні програми для пенсіонерів серед перелічених банківських установ пропонує лише АТ “Ощадбанк".
В табл. 3 подано інформацію про пенсійні депозити, які українські банки пропонують клієнтам на строк від 1 року з можливістю пролонгації. Як видно з таблиці депозити з найвигіднішими умовами пропонують банки з невеликими частками на ринку роздрібних депозитів. Натомість банки, що належать до переліку найнадійніших, зокрема АТ "УКРСИББАНК”, пропонують

Пенсійні депозитні програми банків України в 2019 р. *

Таблиця 3

\begin{tabular}{|c|c|c|c|c|c|c|c|}
\hline \multirow[b]{2}{*}{$\begin{array}{c}\text { Банки } \\
\text { (група) }\end{array}$} & \multirow[b]{2}{*}{\begin{tabular}{|c} 
Назва \\
депозит- \\
ної \\
програ- \\
ми
\end{tabular}} & \multicolumn{6}{|c|}{ Умови депозитної програми } \\
\hline & & 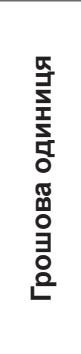 & 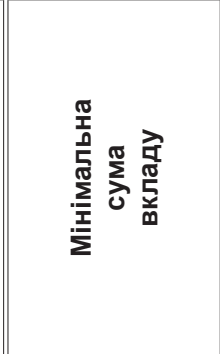 & 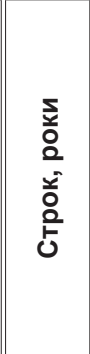 & 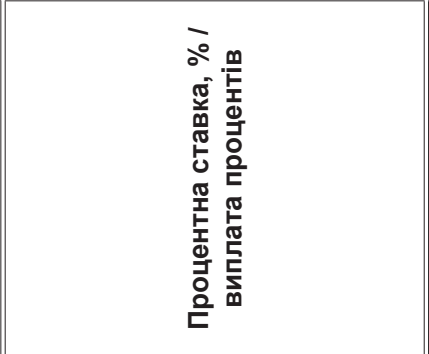 & 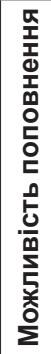 & 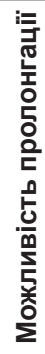 \\
\hline \multirow{5}{*}{$\begin{array}{l}\text { ПАТ АКБ “Львів” } \\
\text { (банки з приватним } \\
\text { капіталом) }\end{array}$} & \multirow{5}{*}{$\begin{array}{c}\text { Пенсій- } \\
\text { ний }\end{array}$} & \multirow{2}{*}{ грн } & \multirow{2}{*}{1000} & $1-1,5$ & 18 / щомісячно & + & + \\
\hline & & & & $1,5-2$ & 17 / щомісячно & + & + \\
\hline & & $\begin{array}{l}\text { дол. } \\
\text { США } \\
\end{array}$ & 50 & \begin{tabular}{|l|}
$1-1,5$ \\
$1,5-2$ \\
\end{tabular} & 4,75 / щомісячно & + & + \\
\hline & & \multirow{2}{*}{ євро } & 50 & $1,5-2$ & 3,50 / щомісячно & + & + \\
\hline & & & 50 & $1-1,5$ & 3,25 / щомісячно & + & + \\
\hline \multirow{2}{*}{$\begin{array}{l}\text { АТ “БАНК ФОРВАРД” } \\
\text { (банки іноземних } \\
\text { банківських груп) } \\
\end{array}$} & \multirow{2}{*}{$\begin{array}{c}\text { Пенсій- } \\
\text { ний }\end{array}$} & \multirow[b]{2}{*}{ грн } & \multirow{2}{*}{5000} & 1 & 18 / щомісячно & - & + \\
\hline & & & & 2 & 17,75 / щомісячно & - & + \\
\hline \multirow{4}{*}{$\begin{array}{l}\text { ПАТ “МТБ БАНК” } \\
\text { (МАРФІН БАНК) } \\
\text { (банки з приватним } \\
\text { капіталом }\end{array}$} & \multirow{4}{*}{$\begin{array}{c}\text { Пенсій- } \\
\text { ний }\end{array}$} & \multirow{4}{*}{ грн } & \multirow{4}{*}{100} & \multirow{2}{*}{$\mid 1-1,5$} & 16,2 /в кінці строку & \multirow{2}{*}{+} & \multirow{2}{*}{+} \\
\hline & & & & & 16 / щомісячно & & \\
\hline & & & & 155 & 14,1 /в кінці строку & + & + \\
\hline & & & & | $1,5-5$ & 14 / щомісячно & + & + \\
\hline \multirow{6}{*}{$\begin{array}{l}\text { AT “Ощадбанк” } \\
\text { (державні банки) }\end{array}$} & \multirow{6}{*}{$\begin{array}{c}\text { Мій } \\
\text { пен- } \\
\text { сійний } \\
\text { депозит }\end{array}$} & \multirow{3}{*}{ грн } & \multirow{2}{*}{ 1тис. -500 тис. } & \multirow{2}{*}{1} & 14,25 / щомісячно & \multirow{2}{*}{+} & \multirow{2}{*}{+} \\
\hline & & & & & 14,25 / капіталізація & & \\
\hline & & & 1 тис. -500 тис. & 1,5 & 12,5 / щомісячно / капіталізація & + & + \\
\hline & & \multirow{2}{*}{$\begin{array}{l}\text { дол. } \\
\text { США }\end{array}$} & $100-20$ тис. & 1 & 4,00 / щомісячно / капіталізація & + & + \\
\hline & & & $100-20$ тис. & 1,5 & 3,50 /капіталізація/ щомісячно & + & + \\
\hline & & євро & $100-20$ тис. & $1 ; 1,5$ & 2,50 / щомісячно / капіталізація & + & + \\
\hline \multirow{2}{*}{$\begin{array}{l}\text { АТ “УКРСИББАНК” } \\
\text { (банки іноземних } \\
\text { банківських груп) } \\
\end{array}$} & \multirow{2}{*}{$\begin{array}{l}\text { Щасли- } \\
\text { вий вік }\end{array}$} & \multirow{2}{*}{ грн } & \multirow{2}{*}{100} & $1 ; 1,5$ & 5,25 / щомісячно / капіталізація & + & + \\
\hline & & & & 2 & 5,25 / щомісячно / капіталізація & + & + \\
\hline
\end{tabular}

* Побудовано на основі [22]. 
низькі процентні ставки. Суттєвими перевагами окремих депозитних пенсійних програм, на нашу думку, є можливість відкриття депозитного рахунку в іноземній валюті, що дає змогу диверсифікувати валютні ризики, умови пролонгації вкладу, які передбачають надбавку до діючої процентної ставки та правила дострокового розірвання договору, згідно з якими відбувається перерахунок процентів за вкрай низькою ставкою. Перелічені характеристики пенсійних депозитних пропозицій банків, на наш погляд, стимулюють потенційних клієнтів до прийняття виваженого рішення про відкриття пенсійного депозитного вкладу на тривалий строк, що, у свою чергу, забезпечує реалізацію його головної функції - накопичення пенсійних заощаджень.

Водночас деякі українські банки (АТ “АКБ “КОНКОРД”, АТ “ПІРЕУС БАНК МКБ”, АТ "МІБ”, АТ “Ощадбанк” та ін.) [22] пропонують клієнтам-пенсіонерам депозити на строк, менший одного року, депозити без можливості пролонгації й на суму, що значно перевищує гарантовану для відшкодування ФГВФО, що, на нашу думку, нівелює сутність пенсійних депозитів як таких, оскільки вони не відповідають вимогам законодавства до такого виду вкладів.

Аналіз вітчизняного депозитного ринку дає змогу зробити висновок про значний нереалізований потенціал розвитку банківських установ в системі недержавного пенсійного забезпечення, адже банківські депозити є простим, доступним, передбачуваним і гнучким інструментом заощадження пенсійних коштів. Тому в сучасних умовах посткризового відновлення банківської системи України вкрай важливою залишається необхідність розроблення нових і вдосконалення наявних методів підвищення надійності та довіри до банківських установ, забезпечення захисту прав вкладників, доступності якісних банківських послуг широкому загалу потенційних клієнтів із різним рівнем фрінансового стану та інвестиційних цілей.

Висновки. Проведене дослідження дало змогу виокремити основні проблеми розвитку недержавного пенсійного забезпечення в Україні, зокрема відсутність з боку держави масштабної інформаційної кампанії щодо роз'яснення переваг системи накопичувального пенсійного страхування; низький рівень доходів значної частини населення, що неспроможне заощаджувати кошти; зростання недовіри населення до держави та фрінансових інститутів, яка зумовлена низкою фрінансових криз в економіці України; нестабільність національної валюти, яка породжує ризик зниження вартості пенсійних накопичень; незадовільний розвиток фондового ринку та невеликий вибір надійних фрінансових інструментів для розміщення пенсійних активів; відсутність стимулів у роботодавців щодо фрінансування недержавних пенсійних програм через високі внески на загальнообов'язкове державне соціальне страхування; недосконалість законодавства, що регулює відносини у сорері недержавного пенсійного забезпечення; низьку ефрективність податкових стимулів інвестування заощаджень у недержавні пенсійні програми.

3 метою стимулювання розвитку недержавного пенсійного забезпечення, що, як свідчить світова практика, є дієвим інструментом запобігання соціально-економічним загрозам з боку солідарної пенсійної системи та задля забезпечення достойного рівня пенсійних виплат необхідно:

- провести велику державну інформаційну кампанію щодо популяризації недержавного пенсійного забезпечення, пояснити переваги та можливості різних фрінансових інструментів щодо формування пенсійних заощаджень;

- стабілізувати економічну ситуацію в країні, що сприятиме створенню до- 
даткових робочих місць та підвищенню рівня доходів населення;

- розширити коло недержавних фінансових інститутів, які мали б змогу акумулювати пенсійні активи (страхові компанії, інвестиційні фонди, брокерські установи), що створить конкуренцію недержавним пенсійним фоонам та сприятиме підвищенню якості фінансових послуг у сфрері пенсійного забезпечення;

- удосконалити механізм захисту пенсійних накопичень шляхом створення фронду гарантування;

- сприяти розвитку фондового ринку та розширити перелік фрінансових активів, дозволених для інвестування, у тому числі надати можливість інвестувати в надійні іноземні фрінансові інструменти;

- посилити контроль за діяльністю фрінансових інститутів на ринку недержавного пенсійного забезпечення та впровадити гнучкі підходи до регулювання їх діяльності, які базуватимуться на інструментах ризик-орієнтованого нагляду;

- удосконалити систему пільгового оподаткування накопичувальних пенсійних внесків і виплат.

Отже, в сучасних умовах розвитку економіки України ринок недержавного пенсійного забезпечення потребує виважених, раціональних і ефективних управлінських рішень соціально-економічного, нормативно-правового й організаційного характеру для розроблення ефективної стратегії його розвитку.

\section{Список використаних джерел}

1. Конституція України : Закон України від 28.06.1996 року № 254К/96-BP. URL : https:// zakon.rada.gov.ua/laws/show/254\%D0\%BA/96$\% D 0 \% B 2 \% D 1 \% 80$.

2. Ріппа М. Імперативи бюджетного фрінансування соціального захисту і соціального забезпечення в Україні. Світ фрінансів. 2018. Вип. 3(56). С. 28-40.
3. Річні звіти про виконання державного бюджету України за 2007-2018 роки / Державна казначейська служба України. URL : https:// www.treasury.gov.ua/ua/file-storage/vikonannyaderzhavnogo-byudzhetu.

4. Звіти про виконання бюджету Пенсійного фонду України за 2007-2018 роки / Пенсійний фронд України. URL : https://www.pfu.gov.ua/category/ informatsiya/byudzhet/arhiv-zvitnist-byudzhet/.

5. Розмір пенсії в країнах Європи / Migrant. biz.uа. - Правова та юридична допомога. URL : https://migrant.biz.ua/dovidkova/emigracia/pensiiv-krainakh-ievropy.html.

6. Про загальнообов'язкове державне пенсійне страхування : Закон України від 09.07.2003 року № 1058-IV URL : https://zakon.rada.gov.ua/ laws/show/1058-15.

7. Підсумки розвитку системи недержавного пенсійного забезпечення станом на 31.12.2017 / Національна комісія, що здійснює державне регулювання у сфрері ринків фрінансових послуг. URL : https://www.nfp.gov.ua/files/17_ Dep_Repetska/NPF_IV_kv\%202017.pdf.

8. Privat pension assets / OECD data. URL : https://data.oecd.org/pension/private-pensionassets.htm\#indicator-chart.

9. Про недержавне пенсійне забезпечення : Закон України від 09.07.2003 р. № 1057-IV. Дата оновлення: 04.11.2018. URL : https://zakon. rada.gov.ua/laws/show/1057-15.

10. Підсумки розвитку системи недержавного пенсійного забезпечення станом на 31.12.2018 / Національна комісія, що здійснює державне регулювання у сфері ринків фрінансових послуг. URL : https://www.nfp.gov.ua/files/ OgliadRinkiv/NPF/NPF_IV_kv\%202018.pdf.

11. Підсумки розвитку системи недержавного пенсійного забезпечення станом на 31.12.2016 / Національна комісія, що здійснює державне регулювання у сфрері ринків фрінансових послуг. URL : https://www.nfp.gov.ua/files/17_ Dep_Repetska/NPF_IV_kv\%202016.pdf.

12. Аналітичний огляд діяльності індустрії управління активами в Україні за 4-й 
квартал 2018 року та 2018 рік. Недержавні пенсійні фонди / Українська асоціація інвестиційного бізнесу. URL : www.uaib.com.ua/files/ articles/2753/13/3.\%20Q4\%202018\%20\&\%20 FY\%202018_NPF.pdf.

13. Іващенко А., Шульга М. Загальні тенденції розвитку системи недержавного пенсійного забезпечення в Україні. Київ : Oфpic з фрінансового та економічного аналізу у Верховній Раді України, 2017. 29 с.

14. Аналітичний огляд ринку управління активами за 4-й квартал та 2017 рік / Українська асоціація інвестиційного бізнесу. URL : www.uaib.com.ua/files/articles/2660/15/Q4\%20 2017\%20\&\%20Full\%202017_final.pdf.

15. Іващенко А. Накопичувальне пенсійне страхування: досвід Польщі. Київ : Oфріс з фрінансового та економічного аналізу у Верховній Раді України, 2018. Листопад. 30 c. URL : https:// feao.org.ua/products/polandpension/.

16. Рейтинг компаний страхования жизни / Фориншурер страхование. URL: https:// forinsurer.com/ratings/life.

17. Демченко М. Напрями підвищення ефрективності діяльності страхових компаній у сорері накопичувального пенсійного страхування. Соціально-економічні проблеми сучасного періоду України. 2015. Вип. 3 (113). С. 81-85.

18. Третяк Д. Суперечності розвитку недержавного пенсійного забезпечення в Україні. Вісник Київського нац. ун-ту імені Тараса Шевченка. Економіка. 2014. Вип. 1 (154). С. 89-93.

19. Про систему гарантування вкладів фрізичних осіб : Закон України від 23.02.2012 p. № 4452-VI. URL : https://zakon5.rada.gov.ua/laws/ show/4452-17.

20. Інструкція про порядок відкриття $і$ закриття рахунків клієнтів банків та кореспондентських рахунків банків - резидентів і нерезидентів : затв. Постановою Правління НБУ 12.11.2003 року № 492 (у редакції постанови Правління НБУ від 01.042019 року № 56). URL : https://zakon.rada.gov.ua/laws/show/z1172-03.
21. Віннічук Ю. В які банки українці несуть гроші. БІЗНЕС ЦЕНЗОР. 2019. 27 лютого. URL : https://biz.censor.net.ua/r3113283.

22. Депозити для пенсіонерів / Простобанк Консалтине. URL : https://www.prostobank.ua/ depozity/depozity_pensioneram.

\section{References}

1. "Konstytutsiia Ukrainy" : Zakon Ukrainy vid 28.06. 1996 roku No 254K/96-BP. [The Constitution of Ukraine] (1996, June, 28). Available at: https:// zakon.rada.gov.ua/laws/show/254\%D0\%BA/96$\%$ \%0\%B2\%D1\%80.

2. Rippa, M. (2018). Imperatyvy biudzhetnoho finansuvannia sotsialnoho zakhystu i sotsialnoho zabezpechennia v Ukraini [Imperatives of budgetary financing of social protection and social security in Ukraine]. Svit finansiv - World of Finance, 3 (56), 28-40.

3. Richni zvity pro vykonannia derzhavnoho biudzhetu Ukrainy za 2007-2018 roky [Annual reports on the implementation of the state budget of Ukraine for 2007-2018]. Derzhavna kaznacheiska sluzhba Ukrainy. - The State Treasure Service of Ukraine. Available at: https://www.treasury.gov.ua/ua/file-storage/vikonannya-derzhavnogo-byudzhetu.

4. Zvity pro vykonannia biudzhetu Pensiinoho fondu Ukrainy za 2007-2018 roky. [Reports on the implementation of the budget of the Pension Fund of Ukraine for 2007-2018]. Pensiynyi fond Ukrainy The Pension Fund of Ukraine. Available at: https:// www.pfu.gov.ua/category/informatsiya/byudzhet/ arhiv-zvitnist-byudzhet/.

5. Rozmir pensii v krainakh Yevropy [The size of the pension in the countries of Europe]. Migrant. biz.ua. - Pravova ta yurydychna dopomoha. - Migrant.biz.ua. - Legal and juridical assistance. Available at: https://migrant.biz.ua/dovidkova/emigracia/ pensii-v-krainakh-ievropy.html.

6. Pro zahalnooboviazkove derzhavne pensiine strakhuvannia : Zakon Ukrainy vid 09.07.2003 roku No 1058-IV [On Mandatory State Pension Insurance : The Law of Ukraine]. (2003, November 4). Available at: https://zakon.rada.gov.ua/laws/ show/1058-15. 


\section{АКТУАЛЬНІ ПИТАННЯ ТЕОРІЇ І ПРАКТИКИ ФІНАНСІВ}

7. Pidsumky rozvytku systemy nederzhavnoho pensiinoho zabezpechennia stanom na 31.12.2017 [Results of the development of the system of nonstate pension provision dated December 31, 2017]. Available at: https://www.nfp.gov.ua/files/17_Dep_ Repetska/NPF_IV_kv\%202017.pdf.

8. Privat pension assets / OECD data. Available at: https://data.oecd.org/pension/private-pension-assets.htm\#indicator-chart

9. Pro nederzhavne pensiine zabezpechennia: Zakon Ukrainy vid 09.07.2003 roku No 1057IV [On Non-State Pension Provision: The Law of Ukraine] (2003, November, 4). Available at: https:// zakon.rada.gov.ua/laws/show/1057-15.

10. Pidsumky rozvytku systemy nederzhavnoho pensiinoho zabezpechennia stanom na 31.12.2018" [Results of the development of the system of non-state pension provision, dated December 31, 2018]. Available at: https://www.nfp.gov.ua/ files/OgliadRinkiv/NPF/NPF_IV_kv\%202018.pdf.

11. Pidsumky rozvytku systemy nederzhavnoho pensiinoho zabezpechennia stanom na 31.12.2016 [Results of the development of the system of non-state pension provision, dated December 31, 2016]. Available at: https://www.nfp.gov.ua/ files/17_Dep_Repetska/NPF_IV_kv\%202016.pdf.

12. Analitychnyi ohliad diialnosti industrii upravlinnia aktyvamy v Ukraini za 4-i kvartal 2018 roku ta 2018 rik. Nederzhavni pensiini fondy" [Analytical review of the asset management market in Ukraine - Q4 2018 \& Full Year 2018 Results. Non-State Pension Funds]. Ukrainska asotsiatsiia investytsiinoho biznesu - Ukrainian Association of Investment Business. Available at: https://www. uaib.com.ua/files/articles/2753/13/3.\%20Q4\%20 2018\%20\&\%20FY\%202018_NPF.pdf.

13. Ivashchenko, A., Shulha, M. (2017). Zahalni tendentsii rozvytku systemy nederzhavnoho pensiinoho zabezpechennia $v$ Ukraini [The main trends of non-governmental pension administration development in Ukraine]. Kyiv : Ofis z finansovoho ta ekonomichnoho analizu u Verkhovnii Radi Ukrainy - Financial and Economic Analysis Office in the Verkhovna Rada of Ukraine [in Ukrainian].
14. Analitychnyi ohliad rynku upravlinnia aktyvamy za 4-i kvartal ta 2017 rik [Analytical review of the asset management market in Ukraine - Q4 2017 \& Full Year 2017 Results]. Ukrainska asotsiatsiia investytsiinoho biznesu - Ukrainian Association of Investment Business. Available at: www.uaib. com.ua/files/articles/2660/15/Q4\%202017\%20 \&\%20Full\%202017_final.pdf.

15. Ivashchenko, A. (2018). Nakopychuvalne pensiine strakhuvannia: dosvid Polshchi [Accumulation pension insurance: Polish experience]. Kyiv : Ofis z finansovoho ta ekonomichnoho analizu $u$ Verkhovnii Radi Ukrainy - Financial and Economic Analysis Office in the Verkhovna Rada of Ukraine [in Ukrainian].

16. Reiting kompanii strakhovaniia zhizni [Rating of life insurance companies]. Forinshurer strakhovaniie - Forinsurer insurance. Available at: https://forinsurer.com/ratings/life.

17. Demchenko, M. (2015). Napriamy pidvyshchennia efektyvnosti diialnosti strakhovykh kompanii u sferi nakopychuvalnoho pensiinoho strakhuvannia [Directions of increase of efficiency of activity of insurance companies in the field of accumulative pension insurance]. Sotsialno-ekonomichni problemy suchasnoho periodu Ukrainy Socio-economic problems of the modern period of Ukraine, 3 (113), 81-85 [in Ukrainian].

18. Tretiak, D. (2014). Superechnosti rozvytku nederzhavnoho pensiinoho zabezpechennia $v$ Ukraini [Contradictions of the development of Non-State pension provision in Ukraine]. Visnyk Kyivskoho natsionalnoho universytetu imeni Tarasa Shevchenka. Ser. Ekonomika - Bulletin of Taras Shevchenko National University of Kyiv. Ser. Economics, 1 (154), 89-93 [in Ukrainian].

19. Pro systemu harantuvannia vkladiv fizychnykh osib : Zakon Ukrainy vid 23.02.2012 roku No 4452-VI [On the System of Guaranteeing Natural Person Deposits : The Law of Ukraine]. (2012, February, 23). Available at: https://zakon5.rada. gov.ua/laws/show/4452-17.

20. Instruktsiia pro poriadok vidkryttia i zakryttia rakhunkiv kliientiv bankiv ta korespondentskykh 


\section{АКТУАЛЬНІ ПИТАННЯ ТЕОРІЇ І ПРАКТИКИ ФІНАНСІВ}

rakhunkiv bankiv - rezydentiv i nerezydentiv: zatv. Postanovoiu Pravlinnia NBU 12.11.2003 roku No 492 (u redaktsii postanovy Pravlinnia NBU vid 01.04 2019 roku No 56) Instruction on the procedure for opening and closing accounts of bank clients and correspondent accounts of banks - residents and non-residents [approved by NBU Board Resolution from November 122003 No 492] editorship of the Board Resolution]. (2019, April, 1). Available at: https://zakon.rada.gov.ua/laws/show/z1172-03.
21. Vinnichuk, Ju. (2019). V yaki banky ukraintsi nesut hroshi [In what banks Ukrainians invest money]. BIZNES TSENZOR - BUSINESS CENSOR. Available at: https://biz.censor.net.ua/r3113283.

22. Depozyty dlia pensioneriv [Deposits for pensioners]. Prostobank Konsaltynh - Prostobank Consulting. Available at: https://www.prostobank. ua/depozity/depozity_pensioneram.

Стаття надійшла до редакції 11.02.2019. 